\title{
EHMTI-0025. Clinical manifestations of subarachnoid hemorrhage from gnathostoma spinigerum in srinagarind hospital
}

\author{
K Sawanyawisuth ${ }^{*}$, W Waranon², K Pongtipakorn ${ }^{1}$, K Kongbunkiat ${ }^{1}$, P Limpawattana ${ }^{1}$, V Senthong ${ }^{1}$, \\ J Chindaprasirt ${ }^{1}$, V Chotmongkol ${ }^{1}$, J Kanpittaya ${ }^{2}$, PM Intapan ${ }^{3}$, W Maleewong ${ }^{3}$, A Kitkhuandee ${ }^{4}$ \\ From 4th European Headache and Migraine Trust International Congress: EHMTIC 2014 \\ Copenhagen, Denmark. 18-21 September 2014
}

\section{Introduction}

Subarachnoid hemorrhage (SAH) is a serious neurological condition. Common cause of SAH is vascular origin. Gnathostomiasis is also a common disease in Thailand and may cause SAH.

\section{Aim}

This study aimed to find clinical differences between SAH caused by both causes.

\section{Methods}

This was a retrospective study and collected data from medical charts of patients diagnosed as SAH at Srinagarind Hospital during 2009 and 2011. SAH caused by vascular causes diagnosed by cerebral angiogram, while cerebral gnathostomiasis diagnosed by negative cerebral angiogram with positive gnathostoma antibody. Clinical features between both groups were compared by descriptive statistics.

\section{Results}

There were 18 patients in vascular group and 10 patients in gnathostomiasis group. Most variables between both groups were comparable except cerebrospinal fluid glucose/plasma glucose. This ratio in gnathostomiasis group was significantly higher than vascular group $(80 \%$ vs $16.67 \%$, respectively).

\section{Conclusion}

Cerebrospinal fluid glucose/plasma glucose ratio was significantly higher in SAH patients caused by gnathostomiasis than vascular group.

No conflict of interest.

\section{Authors' details}

${ }^{1}$ Medicine, Khon Kaen University, Khon Kaen, Thailand. ²Radiology, Khon Kaen University, Khon Kaen, Thailand. ${ }^{3}$ Parasitology, Khon Kaen University, Khon Kaen, Thailand. ${ }^{4}$ Surgery, Khon Kaen University, Khon Kaen, Thailand.

Published: 18 September 2014

\section{doi:10.1186/1129-2377-15-S1-D55}

Cite this article as: Sawanyawisuth et al:: EHMTI-0025. Clinical manifestations of subarachnoid hemorrhage from gnathostoma spinigerum in srinagarind hospital. The Journal of Headache and Pain 2014 15(Suppl 1):D55. (c) 2014 Sawanyawisuth et al; licensee Springer. This is an Open Access article distributed under the terms of the Creative Commons Attribution License (http://creativecommons.org/licenses/by/2.0), which permits unrestricted use, distribution, and reproduction in any medium, provided the original work is properly cited.
Submit your manuscript to a SpringerOpen ${ }^{\circ}$ journal and benefit from:

- Convenient online submission

- Rigorous peer review

- Immediate publication on acceptance

- Open access: articles freely available online

- High visibility within the field

- Retaining the copyright to your article

\section{Submit your next manuscript at $\gg$ springeropen.com}

